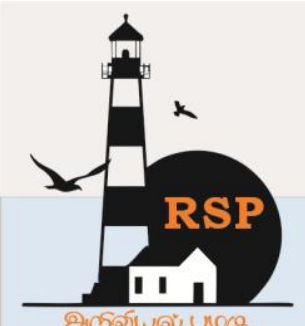

INTERNATIONAL RESEARCH JOURNAL ON ADVANCED SCIENCE HUB

ISSN : $2582-4376$
Open Access

RSP SCIENCE HUB

(The Hub of Research Ideas)

Available online at www.rspsciencehub.com

Special Issue of First International Conference on Advancements in Management, Engineering and Technology (ICAMET 2020)

\title{
Synthesis and Biological Screening of Some New Schiff Base Nickel (II) Complexes
}

\author{
P. Durairaj ${ }^{1}$, P.Venkateswari ${ }^{2}$.D Sruthipriya ${ }^{3}$, Manjunathan $^{4}$, T. Maruthavanan $*^{5}$ \\ ${ }^{1,2}$ Assistant Professor, Department of Chemistry, Vivekananda college of Arts and Sciences for Women \\ (Autonomous), Tiruchengode, Namakkal District-637205. \\ ${ }^{3}$ Department of Chemistry, Vivekanandha college of Arts and Sciences for Women (Autonomous), \\ Tiruchengode, Namakkal District-637205. \\ ${ }^{4}$ AssistantProfessor, Department of Chemistry, Govt. Arts \& Science College, Ponneri, Chennai. \\ $5 *$ Associate Professor, Department of Chemistry, Sona College of Technology, Salem- 636005. \\ drdurairaj@vicas.org',_drt_maruthavanan@yahoo.co.in ${ }^{5}$
}

\begin{abstract}
New Schiff bases Ni (II) complexes are synthesized from the condensation of an ethylenediamine compound with salicylicacid compounds and these coordinate to metal ions via substituted salicyladehydeschiff base and their nickel complexes possess remarkable properties as catalysts in various biological systems, antioxidant activities, antiasthmatic and diabetic activities, anticancer activities, antitumor and cytotoxic activities, pharmaceutical fields. Schiff base ligands and their coordination chemistry of nickel attract much attention because of its biological relevance and its own interesting of coordination chemistry. This review summarizes the application of nickel schiff bases complexes and structures were confirmed by IR, 1HNMR, 13CNMR and Mass Spectra.
\end{abstract}

Keywords: Schiff bases, sub.Salicyladehyde, antioxidant activity, anticancer activity, anticonvulsion and antitumor activity

\section{Introduction}

The new Schiff base nickel complex has been fast developing on account of the wide variety of possible structures for the ligands depending upon the aldehydes and amines. Schiff bases are considered as a very important class of organic compounds, which have wide applications in many biological aspects[1]. Schiff bases derived from an amino and carbonyl compound are important classes of ligands that coordinate to metal ions have been studied extensively [2]. In substituted $(\mathrm{Cl}$ and $\mathrm{Br}$ ) salicyaldehyde derivatives, the $\mathrm{C}=\mathrm{N}$ linkage is essential for biological activity, several substituted( $\mathrm{Cl}$ and $\mathrm{Br})$ salicyaldehyde has been reported to possess remarkable antimicrobial activity, antioxidants [3], antitumor [4], anticonvulsion, Schiff base ligands are potential anticancer activity [5]and biological activities [6].Schiff-base complexes are considered to be among the most important stereo chemical models in main group of coordination chemistry due to their preparative accessibility and structural variety [7].A considerable number of schiff base nickel complexes have potential biological interest, being used as more or less successful models of biological compounds [8]but also they can also be found at key points in the development of inorganic biochemistry, catalysis and optical materials [9].

\section{Experimental}

General Considerations

Melting points are uncorrected and were recorded 
www.rspsciencehub.com

on a REMI Series, Lab India Instrument. TLC analysis was done using pre-coated silica gel plates and visualization was done using iodine. IR spectra were recorded in $\mathrm{KBr}$ on Schimadzu FT-IR Spectrometer. ${ }^{1} \mathrm{H} \quad \&{ }^{13} \mathrm{C}$-NMR spectra were recorded on a Bruker (AC $400 \mathrm{MHz} \& 100 \mathrm{MHz})$ using TMS as an internal standard. Elemental analysis was carried out on a Perkin-Elmer seriesII CHNS/O Analyzer 2400. All the chemicals were obtained from Aldrich and all the solvents used were of commercial grade only.

\subsection{Synthesis of Schiff base}

The Schiff base was prepared by condensation of 5-chloro salicylaldehyde $(0.01 \mathrm{~mol})$ with ethylenediamine $(0.01 \mathrm{~mol})$ in ethanol $(50-75 \mathrm{~mL})$ and the mixture was refluxed for $2 \mathrm{hrs}$. The resulting solution was cool and poured in to ice cubes. The product was collected by filtration, washed several times with ethanol and recrystallized from hot ethanol and dried. The melting point of the resulting schiff base was found, m.p. $145^{\circ} \mathrm{C} .55 \%$ yields.

\section{General experimental procedure for the preparation of the complexes}

A mixture of the schiff base under investigation $(0.01 \mathrm{~mol})$ in $25 \mathrm{ml}$ ethanol and the same amount of the same solvent of metal salt (0.01 mol) $\left(\mathrm{MX}_{2}\right.$, where $\mathrm{M}=\mathrm{Ni}$ (II), Co (II), $\mathrm{Cu}$ (II) and $\mathrm{Mn}(\mathrm{II}) ; \mathrm{X}=\mathrm{Cl} / \mathrm{Br} /$ acetates ) were refluxed for 3 hours at $80-90^{\circ} \mathrm{C}$ on water bath . On cooling, colored solid product was collected by filtration and then washed several times with hot ethanol until the washing becomes colorless. The product was dried in air and stored in a desiccator over anhydrous $\mathrm{CaCl}_{2}$ under vacuum. All the metal complexes are colored and stable to air and moisture.

\section{i). The complex, $\mathrm{C}_{34} \mathrm{H}_{34} \mathrm{Cl}_{2} \mathrm{MnN}_{4} \mathrm{Ni}_{2} \mathrm{O}_{4}$}

Pale brown solid. M.p. $145^{\circ} \mathrm{C}$; M.Wt.: 805. 88; Anal. Calc. forC ${ }_{34} \mathrm{H}_{34} \mathrm{Cl}_{2} \mathrm{MnN}_{4} \mathrm{Ni}_{2} \mathrm{O}_{4}: \mathrm{C}, 50.67 ; \mathrm{H}$, 4.25; N, 6.95; O, 7.94; \% found: C,50.79; H,4.15; $\mathrm{N}, 6.87$; O, 7.80; Main IR Peaks $\left(\mathrm{KBr}, \mathrm{cm}^{-1}\right)$ : $v(\mathrm{C}=\mathrm{N}) 1690$.

\section{ii). The complex, $\mathrm{C}_{34} \mathrm{H}_{34} \mathrm{Cl}_{2} \mathrm{CoN}_{4} \mathrm{Ni}_{2} \mathrm{O}_{4}$}

Solid.M.p. $131^{\circ} \mathrm{C}$; M.Wt.809.88; Anal.Calc for $\mathrm{C}_{34} \mathrm{H}_{34} \mathrm{Cl}_{2} \mathrm{CoN}_{4} \mathrm{Ni}_{2} \mathrm{O}_{4}$ : C, 50.42; H, 4.23; N, 6.92; O, 7.90; \% found: C, 50.65; H, 4.13; N, 6.70; O,
Volume 02 Issue 10S October 2020

7.54\%; Main IR Peaks ( $\left.\mathrm{KBr}, \mathrm{cm}^{-1}\right): v(\mathrm{C}=\mathrm{N}) 1654$.

iii).The complex, $\mathrm{C}_{34} \mathrm{H}_{34} \mathrm{Br}_{2} \mathrm{CoN}_{4} \mathrm{Ni}_{2} \mathrm{O}_{4}$

Brown solid, M.p. $128^{\circ} \mathrm{C}$; M.Wt.898.78; Anal.Calc.for $\mathrm{C}_{34} \mathrm{H}_{34} \mathrm{Br}_{2} \mathrm{CoN}_{4} \mathrm{Ni}_{2} \mathrm{O}_{4}$ : C, 45.44; H, 3.81 ; N 6.23 ; O, 7.12; \% Found: C, 45.20; H, 4.47; N, 6.43; O, 7.05\%; Main IR Peaks (KBr, cm $\left.{ }^{1}\right): v(\mathrm{C}=\mathrm{N}) 1647$.

\section{iv). The complex, $\mathrm{C}_{34} \mathrm{H}_{34} \mathrm{Br}_{2} \mathrm{MnN}_{4} \mathrm{Ni}_{2} \mathrm{O}_{4}$}

Pale brown solid.M.p. $135^{\circ} \mathrm{C}$; M. Wt.817.8103; Anal.Calc.for $\mathrm{C}_{34} \mathrm{H}_{34} \mathrm{Br}_{2} \mathrm{MnN}_{4} \mathrm{Ni}_{2} \mathrm{O}_{4}: \mathrm{C}, \quad 45.64 ; \mathrm{H}$, 3.83; N, 6.26; O, 7.15; \% Found: C, 45.54; H, 3.71; N, 6.55; O, $7.33 \%$; Main IR Peaks ( $\mathrm{KBr}$, $\left.\mathrm{cm}^{-1}\right): v(\mathrm{C}=\mathrm{N}) 1660$.

\section{v). The complex, $\mathrm{C}_{34} \mathrm{H}_{34} \mathrm{C}_{12} \mathrm{~N}_{4} \mathrm{Ni}_{3} \mathrm{O}_{4}$}

Pale yellow solid.M.p. $116^{\circ} \mathrm{C}$; M. Wt.809.64; Anal.Calc. for $\mathrm{C}_{34} \mathrm{H}_{34} \mathrm{C}_{12} \mathrm{~N}_{4} \mathrm{Ni}_{3} \mathrm{O}_{4}: \mathrm{C}, 50.44 ; \mathrm{H}$, 4.23; N, 6.92; O, 7.90; found $\mathrm{C}, 50.55 ; \mathrm{H}, 4.31 ; \mathrm{N}$, 6.78; O, $7.70 \%$; Main IR Peaks $\left(\mathrm{KBr}, \mathrm{Cm}^{-1}\right)$ : $v(\mathrm{C}=\mathrm{N}) 1660$.

\section{vi). The complex, $\mathrm{C}_{34} \mathrm{H}_{34} \mathrm{Br}_{2} \mathrm{CuN}_{4} \mathrm{Ni}_{2} \mathrm{O}_{4}$}

Brown solid. M.p. $140^{\circ} \mathrm{C}$;M. Wt.: 903.39; Anal.Calc. for $\mathrm{C}_{34} \mathrm{H}_{34} \mathrm{Br}_{2} \mathrm{CuN}_{4} \mathrm{Ni}_{2} \mathrm{O}_{4}$ : C, 45.20; $\mathrm{H}$, $3.79 ; \mathrm{N}, 6.20 ; \mathrm{O}, 7.08 \% ; \mathrm{C}, 45.33 ; \mathrm{H}, 3.66 ; \mathrm{N}$, 6.07; O, 7.21\%; Main IR Peaks $\left(\mathrm{KBr}, \mathrm{Cm}^{-1}\right)$ : $v(\mathrm{C}=\mathrm{N}) 1666$.

\section{vii). The complex, $\mathrm{C}_{34} \mathrm{H}_{34} \mathrm{C}_{12} \mathrm{CuN}_{4} \mathrm{Ni}_{2} \mathrm{O}_{4}$}

Sunset yellow Solid. M.p. $147^{\circ}$ C;M. Wt.: 814.49; Anal.Calc. for $\mathrm{C}_{34} \mathrm{H}_{34} \mathrm{C}_{12} \mathrm{CuN}_{4} \mathrm{Ni}_{2} \mathrm{O}_{4}: \mathrm{C}, 50.14 ; \mathrm{H}$, $4.21 ; \mathrm{N}, 6.88 ; \mathrm{O}, 7.86 \% ; \mathrm{C}, 50.43 ; \mathrm{H}, 4.06 ; \mathrm{N}$, 6.70; O, 7.91\%; Main IR Peaks $\left(\mathrm{KBr}, \mathrm{Cm}^{-1}\right)$ : $v(\mathrm{C}=\mathrm{N}) 1670$.

\section{viii). The complex, $\mathrm{C}_{34} \mathrm{H}_{34} \mathrm{Br}_{2} \mathrm{~N}_{4} \mathrm{Ni}_{3} \mathrm{O}_{4}$}

Brown solid. M.p. $138^{\circ} \mathrm{C}$;M. Wt.: 898.54; Anal.Calc. for $\mathrm{C}_{34} \mathrm{H}_{34} \mathrm{Br}_{2} \mathrm{~N}_{4} \mathrm{Ni}_{3} \mathrm{O}_{4}: \mathrm{C}, 45.45 ; \mathrm{H}$, $3.81 ; \mathrm{N}, 6.24 ; \mathrm{O}, 7.12 \% ; \mathrm{C}, 45.56 ; \mathrm{H}, 3.76 ; \mathrm{N}$, 6.62; O, 7.51\%; Main IR Peaks $\left(\mathrm{KBr}, \mathrm{Cm}^{-1}\right)$ : $v(\mathrm{C}=\mathrm{N}) 1662$.

\section{Results and Discussion}

The condensation of 5-choloro salicylaldehyde and ethylenediamine in ethanol yields a single product according to following reaction [10] [11]. 


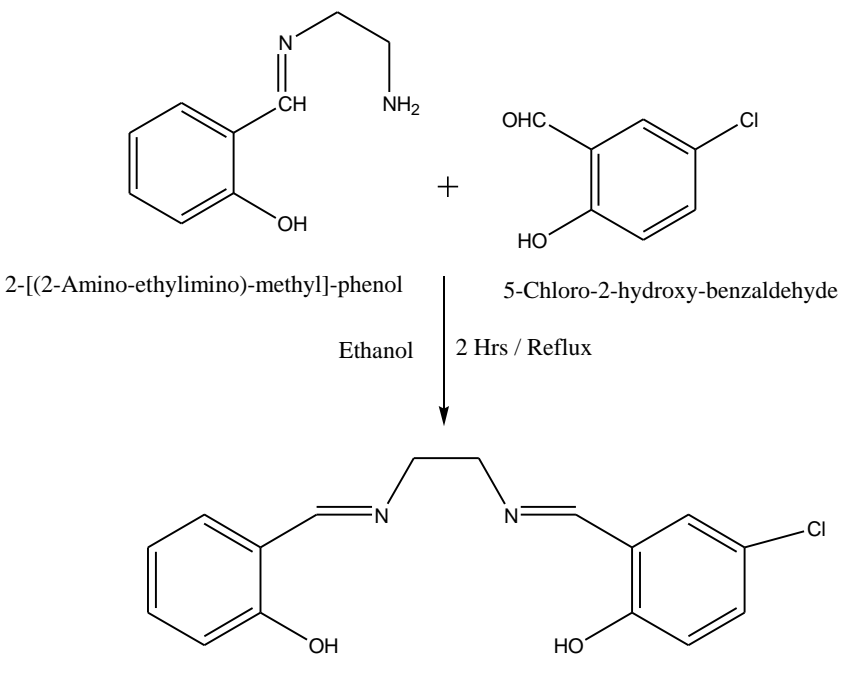

4-Chloro-2-(\{2-[(2-hydroxy-benzylidene)-amino]-ethylimino $\}$-methyl)-phenol

Fig.1. Reaction Scheme-1

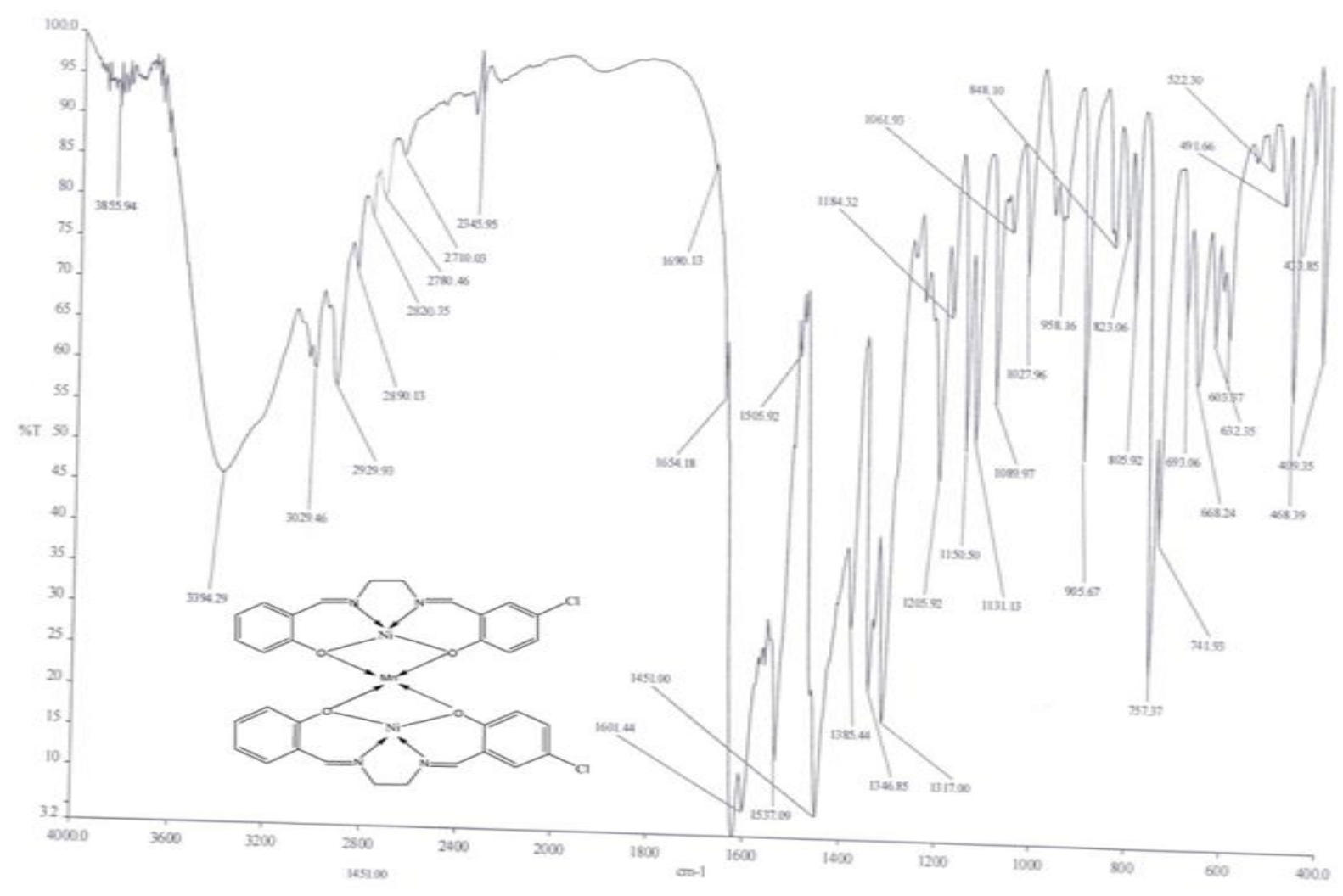

Fig.2.FTIR spectrum of $\mathbf{C}_{\mathbf{3 4}} \mathbf{H}_{\mathbf{3}} \mathbf{C l}_{\mathbf{2}} \mathbf{M n N} \mathbf{N}_{\mathbf{4}} \mathbf{N i}_{\mathbf{2}} \mathbf{O}_{4}$ Complex.

5. Infrared spectra of the Schiff base and its complexes

The IR spectra provide valuable information regarding the nature of functional group attached to the metal atom. In order to study the bonding mode of schiffbase to the metal complexes, the IR spectrum of the free ligand is the compared with the spectra of the complexes. The main IR bands and their assignments are noted. The IR band assignments of all metal complexes exhibit broad 


\section{www.rspsciencehub.com}

bands in the range of 3354 to $3423 \mathrm{~cm}^{-1}$ indicating the presence of coordinated water molecules [12]. A band at $1692 \mathrm{~cm}^{-1}$ in free Schiff base is due to C $=\mathrm{N}$ vibration. The shifting of this group to lower frequency $\left(1654-1690 \mathrm{~cm}^{-1}\right)$ in the metal complexes when compared to free ligand, suggests the coordination of metal ion through nitrogen atom [13]. It is expected that coordination of nitrogen to the metal atom would reduce the electron density and thus lower the $-\mathrm{HC}=\mathrm{N}$ absorption.The $\mathrm{C}-\mathrm{O}$ (Phenolic) stretching frequency of ligand is seen at $1385 \mathrm{~cm}^{-1}$ which gets shifted to a lower frequency region in the complexes in the range of 1346-1317

$\mathrm{cm}^{-1}$, and this is indicative of bonding through phenolic oxygen [14].

New bands, which are not present in the spectrum of ligand appeared in the spectra of complexes in the range of $522-603 \mathrm{~cm}^{-1}$, corresponding to M-
$\mathrm{N}$ [15] [16] and 409-433 $\mathrm{cm}^{-1}$ toM-O vibrations respectively. The appearance ofM-N andM-O vibration supports the involvement of $\mathrm{N}$ and $\mathrm{O}$ atoms in complexation with metal ions under investigation [17-22]. Therefore the IR spectral data indicate that the coordination sites of the metal ion are $-\mathrm{C}=\mathrm{N},-\mathrm{C}-\mathrm{O}$ and Ar-O.

\section{$5.1 .{ }^{1} \mathrm{H}$ and ${ }^{13} \mathrm{C}$-NMR spectra}

The ${ }^{1} \mathrm{H}$ NMR spectrum of the ligand in $\mathrm{CDCl}_{3}$ shows the following signals given in Table. The phenyl multiplet is seen at $\delta 7.02,7.68(\mathrm{~m}, \mathrm{Ar}-$ $\left.\mathbf{H}_{\mathbf{a}, \mathbf{b}} / \mathbf{H}_{\mathbf{e}, \mathbf{g}}\right)$ and the proton is seen at 6.83, $6.60(s$, $\left.\operatorname{Ar}-\mathbf{H}_{\mathbf{c}, \mathbf{f}} \mathbf{f} \mathbf{H}_{\mathbf{h}}\right)$. The peak at $\delta 8.38\left(s, \operatorname{Ar}-\mathbf{H}_{\mathbf{d}, \mathbf{e}}\right)$ is attributed to present in the ligand. The peak at $\delta$ 3.57 is assigned to $-\mathrm{CH}_{3}$ methyl group, on the benzene ring while peak at $\delta 4.00$, which is attributed to $-\mathrm{CH}_{2}$ protons of the methylene proton.

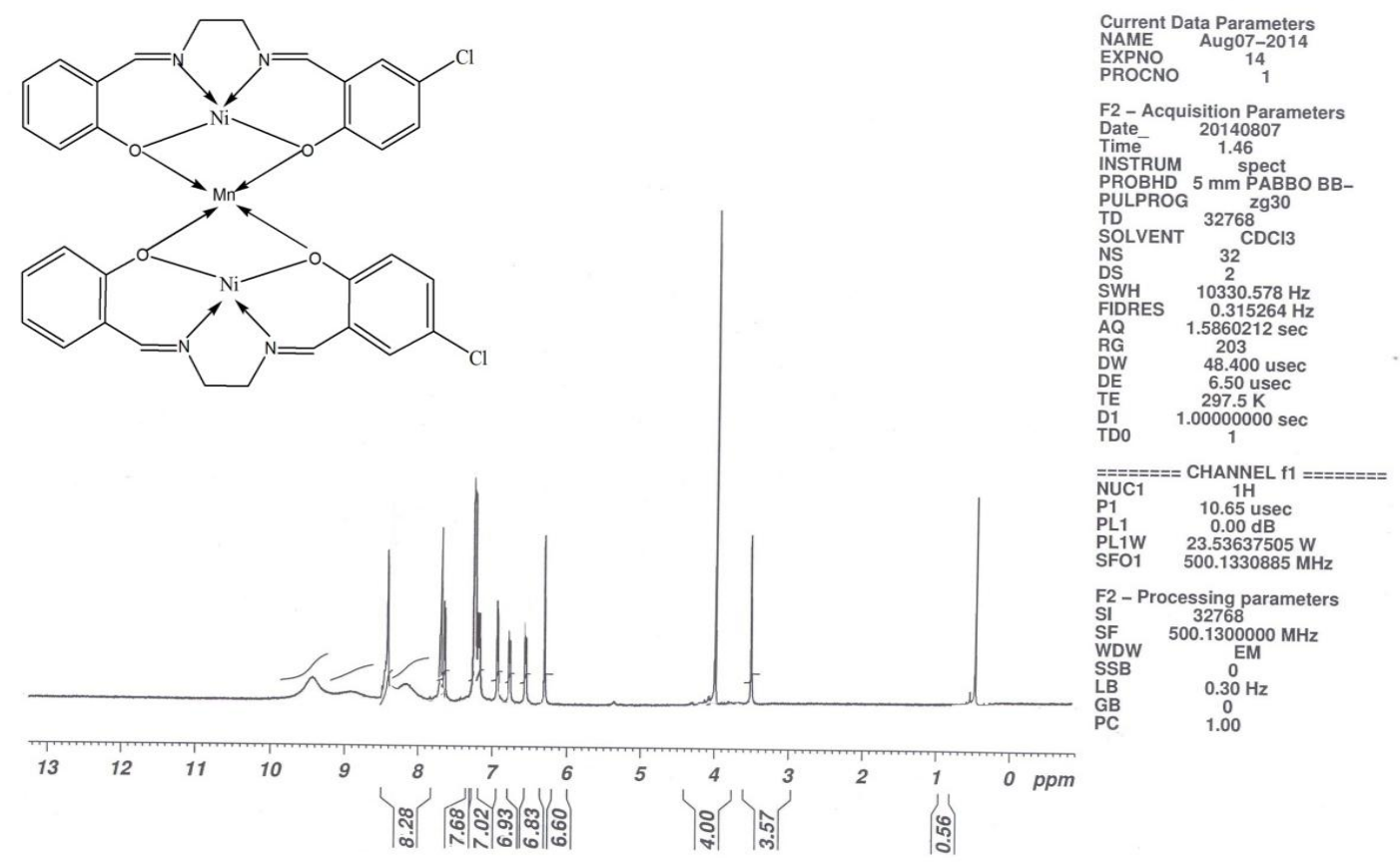

Fig.3.1HNMR \& 13C NMR spectrum of $\mathbf{C}_{\mathbf{3 4}} \mathbf{H}_{\mathbf{3 4}} \mathbf{C l}_{\mathbf{2}} \mathbf{M n N} \mathbf{N}_{\mathbf{4}} \mathbf{N i}_{\mathbf{2}} \mathbf{O}_{\mathbf{4}}$ Complex

The ${ }^{13} \mathrm{C}$ NMR spectrum of the ligand is recorded in $\mathrm{CDCl}_{3}$ and the spectral data confirms the ${ }^{1} \mathrm{H}$ NMR spectral results. The number of signals in the ${ }^{13} \mathrm{C}-\mathrm{NMR}$ spectrum corresponds to the number of magnetically non-equivalent carbon atoms in the ligand. The carbon atom is observed at 156.00 ppm and the phenolic carbon is seen at 165.430 ppm. Large chemical shift values for the carbon atoms attached to the nitrogen, phenolic oxygen and carboxylic oxygen suggest coordination of these atoms. Peaks in the region $113.0-162.004$ ppm are due to aromatic carbons. Methyl carbon is 
observed at 55.580 ppm.Massspectram/z $(\%)$ at $807(80 \%), 609$ (77\%), $470(68.5 \%), 431(100$ \%),297 (32\%), 290 (11\%), 206 (14\%), 140 (45\%) the elemental analysis data of the Schiff base and complexes are in well agreement with the expected structure.

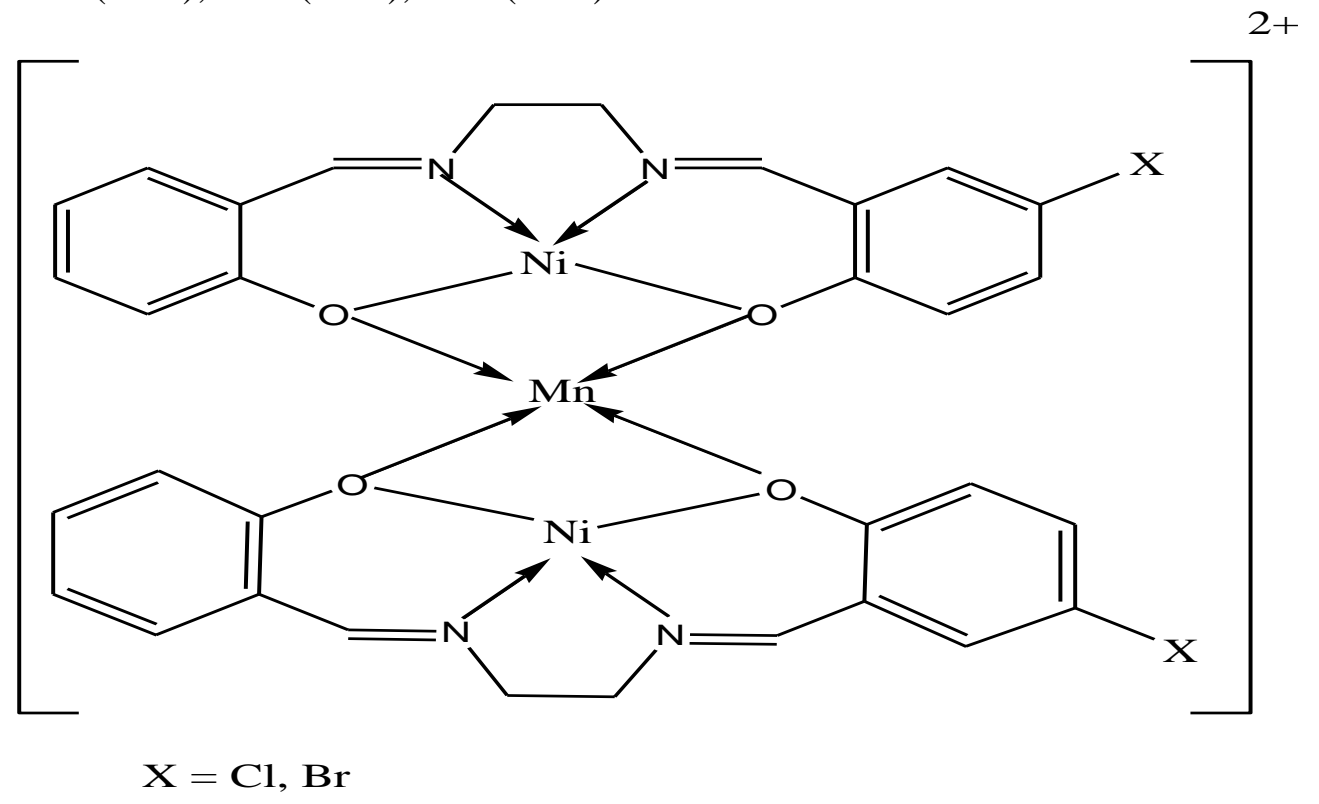

Fig.4. Proposed structure of $\mathbf{C}_{\mathbf{3 4}} \mathbf{H}_{\mathbf{3} 4} \mathbf{C l}_{\mathbf{2}} \mathbf{M n N} \mathbf{N}_{\mathbf{4}} \mathbf{N i}_{\mathbf{2}} \mathbf{O}_{\mathbf{4}}$ Complex

\section{Biological Screening of Compounds Antiasthmatic Activity}

All the above compounds were screened for their potential antiasthmatic activities such as, they were tested against PDE-IV for potential antiasthmatic effect, and against DPP-IV and PTP1B for potential anti-diabetic effects. Moderate activity was found. The antiasthmatic activity was carried out using phosphodiesterase IV enzyme (PDE-IV) (Table.1) and the primary screening of the compounds was done at $1 \mu \mathrm{M}$ concentration using human PDE-IV enzyme, where Rolipram\&Ariflo were used as standard compounds.

\subsection{Antidiabetic Activity}

The anti-diabetic activity was carried out with dipeptidyl peptidase (DPP-IV) enzyme (Table 1) and the primary screening of the compounds was carried at $300 \mu \mathrm{M}$ concentration using recombination human DPP-IV enzyme by the use of 1-(2-amino-3,3-dimethylbutanoyl pyrrolidine-2carbonitrile as the standard compound at $100 \mu \mathrm{M}$. Similarly, the PTP1B (in house compound, also for antidiabetic) activity (Table.7-9) was done using the test compounds at $30 \mu \mathrm{M}$ with the standard compound N-[5-[N-acetyl-4-[N-(2-
carboxyphenyl)-N-(2-hydroxyoxalyl)amino]-3ethy- DL- phenylalanyl - amino] - pentanoyl]-Lmethionine at a concentration of $0.3 \mu \mathrm{M}$.

\subsection{Protocol for PDE-IV inhibition assay}

Phosphodiesterase IV enzyme converts $\left[{ }^{3} \mathrm{H}\right]$ cAMP to the corresponding $\left[{ }^{3} \mathrm{H}\right] 5$ '-AMP in proportion to the amount of phosphodiesterase IV present. The $\left[{ }^{3} \mathrm{H}\right] 5^{\prime}$-AMP then was quantitatively converted to free $\left[{ }^{3} \mathrm{H}\right]$ adenosine and phosphate by the action of snake venom 5 '-nucleotidase and hence the amount of $\left[{ }^{3} \mathrm{H}\right]$ adenosine librated is proportional to phosphodiesterase IV activity.

The assay was performed at $34{ }^{\circ} \mathrm{C}$ in a $200 \mathrm{~mL}$ total reaction mixture. The reaction mixture contained $25 \mathrm{mM}$ of tris buffer, $10 \mathrm{mM} \mathrm{MgCl}_{2}$, $1 \mu \mathrm{M}$ cAMP (cold) and $\left[{ }^{3} \mathrm{H}\right] \mathrm{cAMP}(0.1 \mu \mathrm{Ci})$. Stock solutions of the compounds to be investigated were prepared in dimethyl sulfoxide in concentrations such that the dimethyl sulfoxide content in the test samples did not exceed $0.05 \%$ by volume to avoid affecting the phosphodiesterase IV activity. Compounds were then added in the reaction mixture $(25 \mu \mathrm{L} /$ tube). The assay was initiated by addition of enzyme mix $(75 \mu \mathrm{L})$ and the mixture was incubated for 20 minutes at $34{ }^{\circ} \mathrm{C}$. The 
www.rspsciencehub.com

reaction was stopped by boiling the tubes for $2 \mathrm{~min}$ at $100{ }^{\circ} \mathrm{C}$ in a water bath. After cooling on ice for 5 minutes and addition of $50 \mu \mathrm{g} 5$ '-nucleotidase snake venom from Crotalusatroxincubation was carried out again for $20 \mathrm{~min}$ at $34{ }^{\circ} \mathrm{C}$. The unreacted substrate was separated from $\left[{ }^{3} \mathrm{H}\right]$ adenosine by addition of Dowex AG IX-8 (400 $\mu \mathrm{L})$, which was pre equilibrated in $(1: 1)$ water: ethanol. Reaction mixture was then thoroughly mixed, placed on ice for 15 minutes, vortexed and centrifuged at $14,000 \mathrm{rpm}$ for $2 \mathrm{~min}$. After centrifugation, a sample of the supernatant (150 $\mu \mathrm{L})$ was taken and added in 24 well optiplatescontaningscinillant $(1 \mathrm{~mL})$ and mixed well. The samples in the plates were then determined for radioactivity in a Top Counter and thePhosphodiesterase IV activity was calculated. Phosphodiesterase IV enzyme was present in quantities that yield $<30 \%$ total hydrolysis of substrate (linear assay conditions). Rolipram and Cilomilast were used as a standard in all assays.

\subsection{Protocol for the DPP-IV assay}

Table 1:Antiasthmatic and Antidiabetic activity of compounds

\begin{tabular}{|c|c|c|c|}
\hline S.No & Compounds & $\begin{array}{c}\text { PDE-IV } \\
(\mathbf{1} \boldsymbol{\mu} \mathbf{\%}) \text { Inhibition }\end{array}$ & $\begin{array}{c}\text { DPP-IV } \\
(\mathbf{0 . 3} \boldsymbol{\mu} \mathbf{M}) \boldsymbol{\%} \text { Inhibition }\end{array}$ \\
\hline 1 & ClNiMnNi & 26.43 & 06 \\
\hline 2 & ClNiCoNi & 27.09 & 04 \\
\hline 3 & BrNiCoNi & 43.90 & 20 \\
\hline 4 & BrNiMnNi & 45.76 & 18 \\
\hline 5 & ClNiNiNi & 24.05 & 05 \\
\hline 6 & BrNiCuNi & 48.44 & 08 \\
\hline 7 & ClNiCuNi & 21.34 & 23 \\
\hline 8 & BrNiNiNi & 44.38 & 16 \\
\hline
\end{tabular}

\section{The Anticancer Activity}

\subsection{In vivo model for evaluation of toxicity and anticancer activity, Animals:}

Syrian golden hamsters, 6-8 weeks of age, weighting 105-120 g used, they were housed under standard conditions and fed with a stock diet and

\section{DPP-IV inhibition measurement in vitro} rate of 7-amino-4-methyl-coumarin (AMC) from synthetic substrate Glycyl-Prolyl-AMC. In brief, the assay was conducted by adding $10 \mathrm{mg}$ of human recombinant Dipeptidyl peptidase-IV enzyme (DPP-IV, available commercially from $\mathrm{R}$ $\&$ D Systems) in $50 \mu \mathrm{L}$ of the assay buffer $(25$ $\mathrm{mM}$ Tris, $\mathrm{pH} 7.4,140 \mathrm{mMNaCl}, 10 \mathrm{mMKCl}, 1 \%$ BSA) to 96 well black flat bottom micro-titer plates. The reaction was initiated by adding $50 \mu \mathrm{L}$ of $100 \mu \mathrm{M}$ substrate Gly-Pro-AMC. The incubation was carried out in the kinetic mode at $30{ }^{\circ} \mathrm{C}$ for $30 \mathrm{~min}$. (Fluorescence was measured using Fluorostar at excitation filter of $380 \mathrm{mM}$ and emission filter of $460 \mathrm{mM}$ ) test compounds and solvent controls were added as $1 \mu \mathrm{L}$ additions. Test compounds were dissolved in DMSO and tested at $300 \mathrm{mM}$ concentration. Percent inhibition was calculated with respect to the solvent control sample (no test compound added). Dipeptidyl peptidase (i.e., antidiabetic)
DPP-IV activity was determined by the cleavage

water ad libitum. Approval of the study protocol was obtained from the Ethics Committee for Research in Animals.

\subsection{Acute and subacute toxicity study}

Acute and subacute toxicity tests were performed according to the OECD guideline for chemicals 
(OECD, 2004). Hamsters (4 males and 4 females for each group) were fed (via gastric gavage) with three dose levels of ethanol with compound (resuspended in a mixture of distilled water and Tween-80, 4:1, v:v), i.e., 1000, 3000, and 5000 $\mathrm{mg} / \mathrm{kg}$ body weight. The control hamsters were fed with the mixture of distilled water and Tween80. Animals were closely observed for awareness, status of mood, motor activity, CNS excitation, posture, muscle tone, reflexes, and autonomic signs during the first 30 minutes, periodically during the first 24 hours, and then daily for 14 days (acute toxicity) or 30 days (subacute toxicity) (OECD 2004). For subacute toxicity test, body weight, and food and water consumption were recorded daily for 30 days. At the end of the observational period, all animals were sacrificed under ether anesthesia and vital organs (brain, heart, kidneys, liver, spleen, stomach, large and small intestine, and lungs) were removed from all animals.

\subsection{OV-DMN induced CCA in hamster model}

Assessment of anticancer activity of the crude ethanol with compound against CCA was performed in sixty hamsters (30 males and 30 females), The parasite species were confirmed under light microscope [18] and were minced and digested with pepsin- $\mathrm{HCl}$, then filtrated and washed with normal saline. Animals were divided into six groups ( 5 males and 5 females each). The first six groups were treated as $\mathrm{OV}$-infected groups. Development of CCA was induced by initial feeding of all animals (by gastric gavage) with 50 metacercariae of $\mathrm{OV}$, followed four weeks later by drinking water containing $12.5 \mathrm{ppm}$ of dimethylnitrosamine (DMN) for eight weeks [19]. 5-FU was used as a positive control treatment (group 1) and the groups consisting of healthy hamsters (group 6) and OV/DMN-induced hamsters without any treatment (group 2) were served as normal control and untreated control groups, respectively. The occurrence and development of CCA was detected and confirmed by ultrasonography throughout the investigation period and finally by histopathology at autopsy. Group I (5- FU treated, positive control): OV/DMN induced CCA hamsters, treated with 5FU (40 $\mu \mathrm{g} / \mathrm{kg}$ body weight, single intravenous injection). Group II (negative control): OV/DMNinduced CCA hamsters treated with vehicle (a mixture of distilled water and Tween-80) daily for 30 days. Group III (high dose-1): OV/DMNinduced CCA hamsters treated with $5,000 \mathrm{mg} / \mathrm{kg}$ body weight crude ethanolic extract of ginger daily for 30 days. Group IV (high dose-2): OV/DMNinduced CCA hamsters, treated with $5,000 \mathrm{mg} / \mathrm{kg}$ body weight crude ethanol with compounds every alternate day for 30 days. Group $V$ (medium dose1): OV/ DMN-induced CCA hamsters, treated with $3,000 \mathrm{mg} / \mathrm{kg}$ body weight crude ethanol with compounds daily for 30 days. Group VI (medium dose-2): OV/DMN-induced CCA hamsters, treated with $3,000 \mathrm{mg} / \mathrm{kg}$ body weight crude ethanol with compounds every alternate day for 30 days. Group VII (low dose-1): OV/DMN-induced CCA hamsters, treated with $1,000 \mathrm{mg} / \mathrm{kg}$ body weight crude ethanol with compounds every alternate day for 30 days Group VIII (normal control): healthy (non-CCA induced) hamsters treated with vehicle (a mixture of distilled water and Tween-80) daily for 30 days. In groups 3-8, the crude extract of ginger was fed to the animals at 12 weeks after induction with $\mathrm{OV}$ metacercariae. Body weight and food and water consumption were recorded daily for 30 days. At autopsy, livers and bile ducts were removed from all animals.

Survival time and survival rate were the primary endpoint parameters for the evaluation of the anticancer activity of the crude ethanol with compounds against CCA.

\subsection{Autopsy and histopathology}

For both toxicity and anticancer activity evaluation, all organs were removed at autopsy and observed macroscopically. Samples were fixed with $10 \%$ formalin solution. Specimens were washed in phosphate buffer three times, then dehydrated in an ascending series of ethanol for 15 min each and embedded in paraffin, followed by sectioning and staining with hematoxylin and eosin [20].

\subsection{Statistical analysis}

Data are expressed as median (range) values. Significant difference between quantitative data of more than two data sets was performed by Kruskal-Wallis test. Significant difference between two quantitative data sets was performed by MannWhitney test. Statistical significance level was set at $\alpha=0.05$ for all tests. 
In vivo model for evaluation of toxicity and Anticancer activity

Toxicity test

For the acute and subacute toxicity studies, single oral doses of crude ethanol with compounds at all of the three levels $(1000,3000$, and $5000 \mathrm{mg} / \mathrm{kg}$ body weight) did not cause mortality in any animal ( $0 \%$ mortality) during the investigation period. Only stomach irritation was observed in all animals immediately after feeding them with the extract. The animals however, recovered from the symptom within one hour of dosing. The average daily intake of water and food, including the average body weight of animals were comparable in all groups. No abnormal histopathology was observed in any vital organ at autopsy.

\subsection{Development of CCA}

Compared with the normal control (group VIII), the average body weights of the animals in groups I-VIII were significantly reduced after DMN withdrawal. Morphology and histology of normal and cancerous hamster are histopathological examination of all OV/DMN induced hamsters (groups I-VIII), but not in the control group (group

VIII), confirmed adenocarcinoma and cholangiofibrosis.

\subsection{Anticancer activity against CCA}

Significant prolongation of survival time was observed in OV/ DMN induced CCA hamsters which were treated with the ethanol with compounds in all treatment regimens compared with both the 5-FU treated (group I) and untreated control (group II) group. Animals started to die as early as 17 weeks in the untreated control group. Median (range) survival time of CCA-bearing hamsters following feeding with all the six treatment regimens was about 3- and 2- times of the untreated and 5-FU treated (positive control) groups, respectively. The extract when given at alternate days for 30 days was found to significantly prolong the survival time of animals compared with the daily dose regimens (Table3). Survival rate at week 58 was $0 \%$ in all groups, except the group treated with the highest dose level of $5,000 \mathrm{mg} / \mathrm{kg}$ every alternate day for 30 days (group VI), of which $2 / 10$ (20\%) of animals still survived (20\% survival rate at week 58 )

Table 3: Survival Time [median (range) values] of 5-FU Treated OV/DMN-induced CCA Hamsters (group I) and Treated OV/DMN Induced CCA Hamsters (groups II-VIII)

\begin{tabular}{|c|c|c|c|c|c|c|c|}
\hline \multirow{2}{*}{\multicolumn{2}{|c|}{ Control hamsters }} & \multicolumn{6}{|c|}{ Treated hamsters } \\
\hline & & \multicolumn{3}{|c|}{ Daily regimen } & \multicolumn{3}{|c|}{ Every alternate regimen } \\
\hline $\begin{array}{l}\text { 5-FU } \\
\text { treated }^{\mathrm{a}} \\
\mathrm{I}\end{array}$ & $\begin{array}{l}\text { Untreated } \\
\text { control }^{b} \\
\text { II }\end{array}$ & $\begin{array}{l}\text { High dose } \\
\text { III }\end{array}$ & $\begin{array}{l}\text { Medium } \\
\text { dose } \\
\mathrm{V} \\
\end{array}$ & $\begin{array}{l}\text { Low dose } \\
\text { VII }\end{array}$ & $\begin{array}{l}\text { High dose } \\
\text { IV }\end{array}$ & $\begin{array}{l}\text { Medium } \\
\text { dose } \\
\text { VI }\end{array}$ & $\begin{array}{l}\text { Low dose } \\
\text { VIII }\end{array}$ \\
\hline $\begin{array}{c}24.5 \\
(22-28) \\
\end{array}$ & $\begin{array}{c}17 \\
(16-20) \\
\end{array}$ & $\begin{array}{c}55 \\
(52-57) \\
\end{array}$ & $\begin{array}{c}50.3 \\
(49-53) \\
\end{array}$ & $\begin{array}{c}47 \\
(44-49) \\
\end{array}$ & $\begin{array}{c}55 \\
(53-58) \\
\end{array}$ & $\begin{array}{c}51.8 \\
(50-55) \\
\end{array}$ & $\begin{array}{c}45.9 \\
(44-49) \\
\end{array}$ \\
\hline
\end{tabular}

${ }^{a}$ Statistically significant difference with Group 2 ( $\left.p<0.001\right)$, Group $3(p<0.001)$, Group $4(p<0.001)$, Group 5 ( $p<0.001)$, Group 7 ( $p<0.001)$, Group 2 ( $p<0.001)$, Group $4(p<0.001)$, and Group $6(p$ $<0.001)$. ${ }^{b}$ Statistically significant difference with Group $3(p<0.001)$, Group 5 ( $\left.p<0.001\right)$, Group 7 ( $p<$ $0.001)$, Group 2 ( $p<0.001)$, Group 4 ( $p<0.001)$, and Group $6(p<0.001)$

\section{Conclusion}

Theligand and its metal complexes of Ni(II) have been structurally characterized. The analytical data show that the metal ligand stoichiometry in all these complexes is 1:2 ratio. All the complexes are non-electrolytes in DMSO solvent. The spectral data show that the ligand act as neutral and tridentate coordinating through nitrogen atom of the nitrogen and oxygen atoms of hydroxyl group of the 5-chlorosalicylaldehyde respectively. Based on analytical, molar conductance and spectral data, all these complexes are assigned to confirmed spectral data. Biological activities of these complexes are moderate active complexes compared with ligand.

\section{Acknowledgements}

The authors are thankful to Principal and Management Committee members of Vivekanandha college of Arts and sciences for women (Autonomous), Tiruchengode, Namakkal District -637205 for providing necessity facilities for this work. 


\section{References}

[1].B. S.Tovrog, D. J. Kitko,R. S.Dragom, J. Am. Chem. Soc.98, 5144 (1976)doi:10.1021/ja00433a016

[2]. P. A.Vigato, S.Tamburini, Coord. Chem. Rev.248, 1717 (2004)

[3]. P. Supaluk,B. Prasit,W. Apilak,I. Chartchalerm,R. Somsak,P. Virapong,Molecules.13(4),904-921 (2008)

[4].S.Etain,D.Abd El-Aziz,E. Abd El-Zaher, E. Ali, SpectroChimicaActa: MolecularandBiomolecular Spectroscopy.79(5), 1331-1337 (2011)

[5]. X. Dongfang,M. Shuzhi,D.Guangyinng, D.Qizhuang ,S.Dazhi.Journal of Rare Earth.26(5), 643-647 (2008)

[6]. J. M.Gemi,C.Biles,J. B Keiser,S. M .Poppe, S. M.Swaney,W.G.Tarapley,D. L. Romeso ,Y. Yage, J. Med. Chem. 43,1034 (2004)

[7]. H.Keypour,M.Rezaeivala, L.Valencia,P. Perez Lourido, H.Raza Khavasi,Polyhedron.28,3755 (2009)

[8]. K. S.Suslick, T. J.Reinert,J. Chem. Educ.62, 974 (1986)

[9].J.Tisato, F. Refosco, F.Bandoli, Coord. Chem. Rev. 135, 325 (1994)

[10].A.Maihub,M. M. El-Ajaily,J. Science Appls.1 (1),275 (2006)

[11]. F. M. Morad, M. M. El-Ajaily,S. Ben Gweirif,J. Science. Appls.1 (1), 72(2007)

[12].B. Jezowska,J. Lisowski,P. Chmielewski, Polyhedron, 7 , 337(1988)doi:10.1016/S02775387(00)80480-5

[13]. J. M. Sece,M. Quiros, M. J. G.Garmendia, Polyhedron,19,1005 (2000) doi:10.1016/S0277-5387(00)00356-9

[14]. L. Lindoy, W. E. Moody, D. Taylor,Inorg. Chem. 16,1962,(1997) doi:10.1021/ic 50174a027 22

[15]. M.Thomas,M. K. M.Nair, P. K. Radhakrishnan, Synth. React. Inorg. Met Org. Chem.25, 471(1995) doi:10.1080/15533179508218235

[16].[16]. K. Nakamoto,Infrared and Raman Spectra of inorganic and coordination Comp.EditionWile, New York, (1997).

[17]. A. Jain, R. Goyal,D. Agarwal,J. Inorganic
Nuclear Chem.43,2005 (1981)

[18].T. Boonmars, Z. Wu, S.Boonjaruspinyo, Parasitol Res, 105, 1273-81(2009)

[19]. S. Tesana,Y. Takahashi, P. Sithithaworn, ParasitolInt, 49, 239-51(2007)

[20].S.Chaimuangraj,W. Thamavit, H. Tsuda, M. A. Moore,Asian Pac J Cancer Prev, 4, 87-93 (2003)

[21].OECD 2001 guideline on acute oral toxicity (AOT): Enviornmental health and safety monograph series on testing and assessment no. 425 .

[22].S. Umukoro,R. B.Ashorobi,J Nat Remedies, 8/2, 242-246 (2008) 